\title{
KONCEPCIA BSC SYSTÉMU A JEJ VYUŽITIE V STRATEGICKOM RIADENÍ PODNIKU AUTOBUSOVEJ DOPRAVY V SR
}

\section{THE CONCEPT OF BSC SYSTEM AND ITS USE IN STRATEGIC MANAGEMENT OF BUS TRANSPORT COMPANY IN SR}

\author{
Eva Kicová1, , Olga Poniščiaková ${ }^{2}$
}

\begin{abstract}
Abstrakt
Strategické riadenie je nevyhnutnou súčast'ou riadenia podniku. Predstavuje spôsob, ako zvýšit' konkurencieschopnost' podnikov. Jednou z možností využitia nástrojov strategického riadenia $v$ spoločnostiach autobusovej dopravy je koncept systému Balanced Scorecard (BSC). Systém BSC pozostáva zo štyroch perspektív - finančnej, zákazníckej, procesnej a perspektívy učenia sa a rastu. Tieto perspektívy využívajú rôzne ukazovatele, ktoré je potrebné pri zavádzaní systému BSC v podniku rešpektovat'. Analyzovali sme, ako podniky v Slovenskej republike využívajú systém BSC v strategickom riadení a výsledky prieskumu sú súčast'ou tohoto príspevku. Jeho ciel'om je vysvetlit' metodiku systému BSC a výhody zavedenia tohto systému v praxi podnikov autobusovej dopravy.
\end{abstract}

Klíčová slova strategický manažment, BSC systém, podniky autobusovej dopravy

Summary Strategic management is an essential part of the business management. It can also be a way to increase the competitiveness of enterprises. One of the possibilities of using strategic management tools in bus transport companies is just the concept of Balanced Scorecard (BSC) system. The BSC system consists of four perspectives - financial, customer, business and learning and growth perspective, which use a lot of indicators. When the enterprise is introducing the BSC system, it should be respected those perspectives. In fact, we analysed how companies in the Slovak Republic use BSC system in their own strategic management. The results of the survey is published in this paper. The aim of this article is to explain the methodology of the BSC system and benefits of implementing this system. It also determined the possibilities of using BSC system in practice, namely in bus transport companies.

Keywords $\quad$ Strategic management, Balanced Scorecard (BSC), Bus transport companies

\section{1 ÚVOD}

Moderné metódy riadenia podnikov si vyžadujú prijímanie a realizáciu takých opatrení, ktorými sa menia zaužívané názory a zvyklosti v prospech zvyšovania efektivity a konkurencieschopnosti podniku na poli trhovej ekonomiky. Koncept BSC systému kombinuje množstvo známych a v praxi overených prvkov riadenia s novými prístupmi $\mathrm{k}$ realizácii stratégie, a tým napíňaniu poslania podniku. $\mathrm{V}$ súčasnosti sa tento strategický nástroj vo svete teší čoraz väčšej obl'ube. Vlastníci, manažéri, ale aj samotní výkonní pracovníci mnohých podnikov oceňujú jeho prínos k prosperite podniku a napíňaniu ciel'ov nielen podniku ako celku,

\footnotetext{
1 Žilinská univerzita v Žiline, FPEDAS, Katedra ekonomiky, Univerzitná 8215/1, 01026 Žilina, SR

2 Žilinská univerzita v Žiline, FPEDAS, Katedra ekonomiky, Univerzitná 8215/1, 01026 Žilina, SR

* korespondenční autor, tel.: +421 917601 584, e-mail: eva.kicova@fpedas.uniza.sk
} 
ale aj osobných ciel’ov samotných zamestnancov. Myslenie z hl'adiska jednotlivých perspektív systému BSC, dôraz aj na nefinančné aspekty činnosti podniku a logický postup v zmysle akceptácie vzt'ahov príčin a následkov vo fungovaní podniku nasmeruje podnik k úspešnému dosiahnutiu svojho poslania a vízie a predstavuje tak nový nástroj riadenia aj v podnikoch autobusovej dopravy.

\section{BSC SYSTÉM A JEHO KONCEPCIA STRATEGICKÉHO RIADENIA}

Balanced Scorecard je manažérska metóda, ktorá k tradičnému pohl'adu na hodnotenie výkonnosti podniku prostredníctvom finančného meradla pridáva d'alšie hl'adiská, ktorými vyjadruje hybné sily budúcej výkonnosti podniku.

Wang (2015) argumentuje, že manažér musí pri meraní výkonnosti organizácie uvažovat'o týchto základných princípoch. Merat' správne prvky - systém musí merat' aktivity, ktoré priamo podporujú produktivitu organizácie. Jasne komunikovat', čo sa meria - meradlá, ktoré sú nedostatočne definované alebo nevýrazne komunikované, nebudú používané alebo pochopené zamestnancom. Konzistentná aplikácia meradiel - ukazovatele musia byt' konzistentné s každým oddelením v organizácii, inak hrozí strata podpory celého systému merania. Udržiavat' meradlá aktívne - ukazovatele musia byt' používané konštruktívnym spôsobom. Nevyužívanie výsledkov podl'a Wang et al. (2015) merania vyústi do identického záveru - nedostatočnej podpory systému merania podnikovej výkonnosti.

Koncepcia BSC sa do podoby, v akej ju poznáme dnes, transformovala od začiatku 90. rokov. Vývoj Balanced Scorecard sa klasifikuje do 3 generácií, ktoré uvádzame s ciel’om identifikovat' zásadné zmeny $\mathrm{v}$ pôvodnej myšlienke. 1. generácia sa datuje od roku 1990, kedy naznačila počiatočná spolupráca Kaplana a Nortona (2007) na výskumnom projekte vo viacerých podnikoch nové smery v meraní podnikovej výkonnosti. Prvá fáza trvala do roku 1992. Za 2. generáciu sa považuje obdobie v strede 90. rokov, pričom závery zahŕňajú Cobbold a Lawrie (2004) v svojej hĺbkovej rešerši o genéze BSC 3. generácia sa datuje ku koncu 90. rokov a početné poznatky zahŕňa vo svojej publikácii Gavurová (2011).

V jednej zo štúdií, ktorú skúmal autor Beard, sa vyskytol pojem „podnikový scorecard“. Ten obsahoval okrem tradičných finančných meradiel, taktiež meradlá týkajúce sa dodacích lehôt, efektívnosti vývoja nových produktov a výrobných cyklov. Diskusia vyústila v rozšírenie scorecardu na Balanced Scorecard, zostaveného zo štyroch perspektív, a to finančnej, zákazníckej, interných procesov a učenia sa a rastu. V konečnom dôsledku sa podl'a Bearda (2015) z Balanced Scorecard ako vylepšeného meracieho systému vyvinul kl'účový manažérsky systém schopný použit' BSC nielen na vyjasnenie a formulovanie stratégie, ale taktiež $\mathrm{k}$ jeho riadeniu.

K d'alšiemu rozšíreniu Balanced Scorecard prispeli autori Kaplan a Norton (2001). Ich spolupráca jasne preukázala dôležitost' prepojenia meradiel metodiky BSC so stratégiou podniku. Skúsenosti z d'alšej spolupráce viedli k spresneniu strategických prepojení scorecardu a preukázali, že dvadsat' až dvadsat'pät' meradiel naprieč štyrmi základnými perspektívami umožňuje formulovat' a implementovat' stratégiu podniku.

Podl'a Bearda (2015) metodika berie do úvahy základnú víziu podniku, ktorú je nevyhnutné presne sformulovat'. Následne definuje štyri strategické oblasti, ktoré sa podiel'ajú na naplánovaní tejto vízie či vízií. Týmito oblast’ami sú financie, vnútorné procesy, učenie sa a rast a samozrejme zákazníci.

Horváth a partneri (2002) hovoria, že hlavným poslaním metodiky BSC je zaistenie implementácie podnikovej stratégie do plánovacích, inovačných a realizačných aktivít podniku, a tým dosiahnut' ich naplnenie. Strategické ciele sú odvodené od vízie a stratégie podniku, a sú rozhodujúce pre celkový úspech. Balanced Scorecard sa zameriava na proces transformácie vízie a stratégie podniku do strategických ciel'ov, ktoré si podnik stanoví. Ďalej sa zameriava na sledovanie, vyhodnocovanie a dodržiavanie definovaného smeru rozvoja podniku a reálneho dosahovania plánovaných výsledkov. Jedná sa teda 
o ucelenú metodiku, ktorá zahŕňa proces strategického riadenia podniku od definície vízie a poslania podniku, až po samotnú implementáciu stratégie na najnižších úrovniach podniku.

Alonso a Cunba (2012) tvrdia, že metodika BSC bola primárne navrhnutá pre vel'ké podniky, ale je možné ju implementovat' i do podniku strednej vel'kosti. Rozdielovým aspektom je to, že pre vel'ké podniky môže byt' hlavnou motiváciou pre implementáciu BSC získavanie podrobného obrazu o podniku, pri podnikoch stredného alebo menšieho charakteru je hlavným motívom vybudovanie vízie a nadväzujúcich ciel'ov. Je však dôležité, aby sa v stredne vel'kých podnikoch z dôvodu zlého zavedenia nestal z metodiky BSC byrokratický nástroj, ktorým podnik stratí flexibilitu.

Horváth (2002) tvrdí, že model stratégie môže byt' úplný len vtedy, ked' podáva odpoved' na otázky týkajúce sa dôležitých oblastí jednania podniku. Určenie finančných ciel'ov je nedostatočné, pokial' nie sú zároveň určené kl'účové ciele, ktoré majú byt' dosiahnuté. Za neúčelné považuje, taktiež oddelené stanovenie ciel'ov. Tak dochádza k opomenutiu vzájomného pôsobenia ciel'ov. Požiadavka je vtedy vzájomne spojená so všetkými dôležitými aspektmi činnosti podniku.

Podl'a Horvátha (2002) rozumieme pod pojmom ciele „základné orientačné princípy“, ktoré ovplyvňujú jednanie ako riadiacich, tak aj výkonných pracovníkov. Podniky v praxi narážajú na problémy s definíciou konkrétnych ciel’ov, spôsobených fragmentáciou názorov, izoláciou konceptov, množstvom analýz a nejasne formulovaných vízií, ktoré v podnikoch existujú. Strategické ciele sa následne odvodia na základe skutočnosti, že metodika Balanced Scorecard porovnávaním všeobecných ciel’ov s jednotlivými perspektívami Balanced Scorecard donúti tvorcov stratégie kich konkretizácií a precíznosti.

Autori Bhagwat a Sharma (2007) konštatujú, že samotné zostavenie metodiky BSC je pomerne komplikované i zdíhavé v praxi a vyžaduje dobrú orientáciu v procesoch týkajúcich sa daného podniku a jeho implementácia môže byt' $v$ praxi vel’mi nákladná a personálne a organizačne náročná. Autorky Fibírová a Šoljaková (2005) hovoria, že metodika BSC kladie dôraz na to, aby finančné a nefinančné meradlá boli súčast'ou informačného systému, ktorý je dostupný pre zamestnanca na všetkých podnikových úrovniach. Dôležité je, aby bolo možné previest' zámery a ciele do konkrétnych meradiel, aby zamestnanci pochopili finančné dôsledky svojich rozhodnutí. Vrcholový manažment musí rozumiet' hybným silám, ktoré zaist'ujú dlhodobý finančný úspech podniku a musí byt' zaistená schopnost' zrozumitel'nej komunikácie v podniku.

Samotný názov metodiky napovedá, že ide o vyvážený, balancovaný scorecard. V reálnom vyjadrení to znamená, že je nutné jednotlivé KPI's spojit' vzájomnými vzt’ahmi a väzbami, ktoré stanovia, akým spôsobom tieto ukazovatele na seba vzájomne pôsobia a ovplyvňujú sa, a zároveň ako pôsobí a ovplyvňuje nadriadený strategický ciel' v každej perspektíve. Grafickým výsledkom tohto projektu je strategická mapa podniku..

\section{VYUŽíVANIE BSC SYSTÉMU AKO NÁSTROJA STRATEGICKÉHO RIADENIA V PODNIKOCH SR}

Metóda Balanced Scorecard sa podl'a Sancha (2016) teší medzi podnikmi vo svete čoraz väčšej obl'ube. Podl'a prieskumu spoločnosti Bain \& Company, ktorá každoročne vyhodnocuje používanie a efektívnost' manažérskych nástrojov medzi organizáciami celého sveta, sa systém BSC prepracoval v poslednom období na 5. priečku v hodnotení desiatich najpoužívanejších manažérskych nástrojov.

V súvislosti s týmto zistením nás zaujímalo, aká je aktuálna pozícia systému BSC na Slovensku. Rozhodli sme sa preto uskutočnit' prieskum s ciel'om objasnit' využívanie a poznanie tohto významného manažérskeho nástroja medzi organizáciami v Žilinskom kraji.

Populáciou, t.j. štatistickým súborom, ktorý je vymedzený ciel’om prieskumu a pre ktorý vyvodzujeme závery, boli podnikatel'ské subjekty pôsobiace na území Žilinského kraja. Prieskum sme realizovali v období január až august 2019 prostredníctvom dotazníka zaslaného respondentom v súlade 
s podmienkami náhodného výberu podl'a Rimalčíka (2007), t. j. pravdepodobnost' zaradenia do vzorky bola pre všetky štatistické jednotky populácie rovnaká a štatistické jednotky boli do vzorky vyberané nezávisle jedna od druhej. Vzorka predstavuje čast' populácie, ktorú sme preskúmali a pre ktorú máme $\mathrm{k}$ dispozícii údaje, pričom ak sú pravidlá výberu štatistických jednotiek do vzorky zvolené v súlade s teóriou pravdepodobnosti, môžeme výsledky zistené vo vzorke zovšeobecnit' na celú populáciu.

Dotazník bol určený manažmentu osloveného subjektu a obsahoval 9 uzatvorených otázok s možnost'ou 1 alebo viacerých odpovedí, pričom niektoré otázky dovol’ovali pod možnost'ou „iné“ uviest' vlastný komentár k problematike. Respondenti boli kontaktovaní prostredníctvom telefónneho hovoru alebo prostredníctvom zaslania e-mailu obsahujúceho internetový odkaz na stránku www.thesistools.com, kde respondent mohol pohodlne vyplnit' a odoslat' dotazník. Kontakty na organizácie boli získané dôkladným, no v princípe jednoduchým vyhl’adávaním na internete. Oslovených bolo 62 subjektov a miera návratnosti dosiahla úroveň $77 \%$.

Prvé tri otázky dotazníka boli zamerané na identifikáciu respondentov. Zaujímal nás počet zamestnancov, výška ročného obratu a sektor národného hospodárstva, v ktorom daná organizácia pôsobí. Z hl'adiska kritéria počtu zamestnancov sa prieskumu zúčastnilo 21 malých podnikov s počtom zamestnancov do 50 , 15 stredných podnikov s počtom zamestnancov od 51 do 250 a 12 vel'kých podnikov s viac ako 250 zamestnancami. Štruktúru respondentov podl'a tohto kritéria znázorňuje obr. 1.

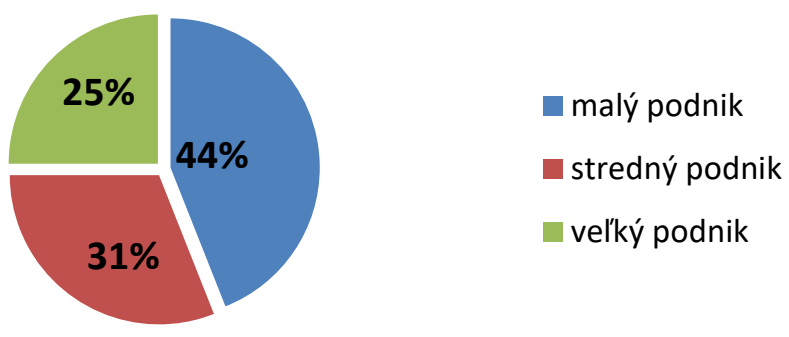

Obr. 1 Štruktúra skúmanej vzorky respondentov, zdroj: vlastné spracovanie

Podl'a vel'kosti ročného obratu tvorili najväčšiu čast' (44\%) podniky s ročným obratom od 10 do 50 mil. € a po $28 \%$ dosiahli podniky s ročným obratom do 10 mil. € a podniky s ročným obratom nad 50 mil. €. Z hl'adiska druhu vykonávanej činnosti zastupovalo primárny sektor 6 organizácií, sekundárny sektor 21 organizácií, terciárny sektor 19 a 2 organizácie pochádzali z kvarciárneho sektora národného hospodárstva.

V štvrtej otázke dotazníka sme sa respondentov pýtali, ktoré manažérske nástroje, resp. metódy používajú. Východiskom pre ich zadanie bola správa spoločnosti Bain \& Company uverejnená pod názvom „Management Tools and Trends 2019“, ktorá každoročne hodnotí používanie a spokojnost’ s 25 populárnymi manažérskymi metódami po celom svete. $V$ súčasnosti spoločnost' disponuje $s$ viac ako 12000 kontaktmi na respondentov, čo jej umožňuje systematicky zist'ovat' efektívnost' celosvetovo využívaných manažérskych nástrojov. Pre účely nášho prieskumu sme respondentom dali na výber 10 najpoužívanejších manažérskych nástrojov v roku 2019 podl'a vyššie uvedenej správy, a to: Balanced Scorecard, Benchmarking, Change Management Programs, Core Competencies, CRM, Employee Engagement Surveys, Formulácia misie a vízie podniku, Outsourcing, Strategické plánovanie a Supply Chain Management. K uvedeným sme doplnili d’alšie, podl’a nášho názoru významné, nástroje, ktorými sú Reinžiniering procesov, Segmentácia zákazníkov, Open Innovation, TQM a respondenti mohli uviest' d'alšie nimi využívané manažérske nástroje pod možnost'ou „iné“.

Zistili sme, že malé podniky využívajú v priemere 3,2 manažérskych nástrojov na podnik, stredné podniky 3,5 nástroja a manažérom vel'kých podnikov pri riadení pomáha v priemere 8,2 nástrojov. Organizácie $\mathrm{v}$ Žilinskom kraji najviac využívajú Outsourcing (73\%), CRM (69\%) a Strategické plánovanie (64\%), 
najmenej sú z uvedených nástrojov používané Change Management Programs (0\%), Balanced Scorecard (4\%) a Reinžiniering procesov (4\%). V možnosti „iné“ neuviedli respondenti žiadny d'alší nástroj.

Nasledujúci graf znázorňuje porovnanie používania manažérskych nástrojov na základe nami realizovaného prieskumu a prieskumu spoločnosti Bain \& Company. Ako vidíme, systém Balanced Scorecard, ktorý je hlavným predmetom nášho záujmu, je celosvetovo využívaný až $38 \%$ podnikov a obsadil 5. priečku po najpoužívanejších nástrojoch Strategické plánovanie, CRM, Employee Engagement Surveys a Benchmarking, kým medzi organizáciami Žilinského kraja je až 12- tym využívaným nástrojom so svojím 4\%-ným podielom.

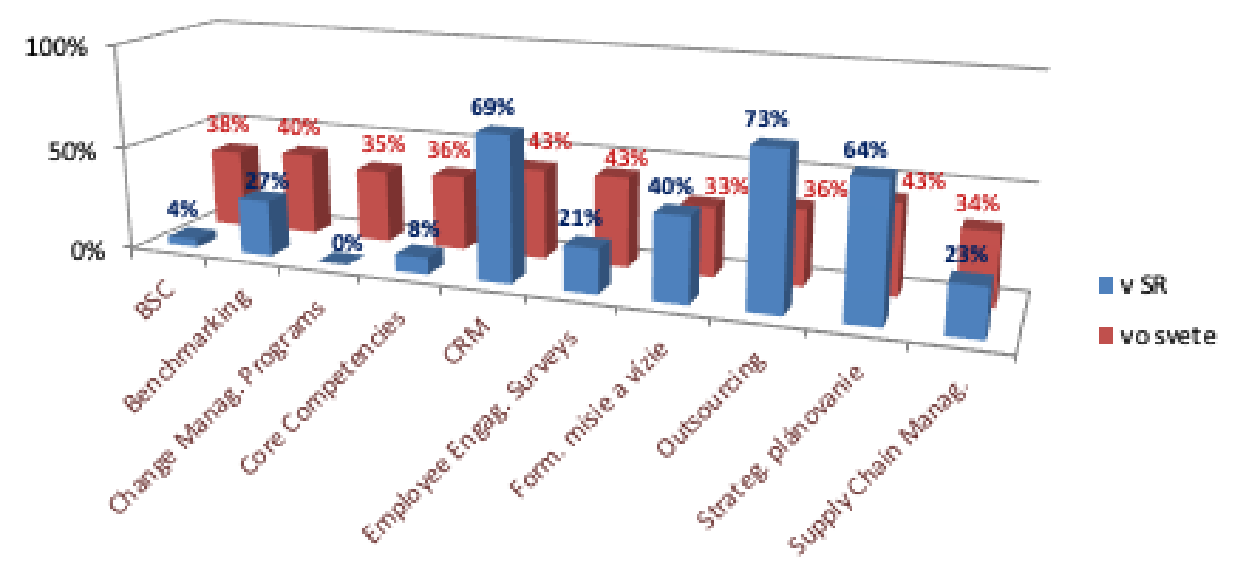

Obr.2 Prehl'ad používania manažérskych nástrojov v SR a vo svete, zdroj: vlastné spracovanie

Piatou a šiestou otázkou nášho dotazníka sme zist’ovali, či si podniky stanovujú dlhodobé ciele, ak áno, v akej oblasti a či majú stratégiu na ich dosiahnutie. Siedma až deviata otázka sa týkala priamo systému Balanced Scorecard, jeho využívania, resp. nevyužívania.

Odpovede respondentov sme graficky znázornili v obr. 3, na základe ktorého možno konštatovat', že podniky si stanovujú dlhodobé ciele, avšak len $20 \%$ respondentov má aj stanovenú stratégiu na ich dosiahnutie. Až 72\% podnikov prehlásilo, že si stratégiu nestanovuje a $8 \%$ účastníkov prieskumu využilo možnost' „neviem“. Smutný je fakt, že napriek tomu, že až $48 \%$ podnikov si stanovuje dlhodobé ciele vo finančných aj nefinančných oblastiach, systém Balanced Scorecard využívajú len $4 \%$ z nich, čo vzhl’adom na vel'kost' našej skúmanej vzorky predstavuje 2 organizácie. Od nich sme na otázku „V čom vidíte najväčšie t'ažkosti pri realizácii BSC“ dostali odpoved', že najväčšie t’ažkosti mali s vyjasnením stratégie, strategických ciel'ov, objektívnych ukazovatel'ov a akcií (1 respondent) a s implementáciou systému v rámci celého podniku (1 respondent). Ostatní respondenti ako dôvod nevyužívania systému BSC uviedli spokojnost' s aktuálnym systémom riadenia, ktorý neplánujú menit’ (36\%), vysoká finančná, organizačná a časová náročnost' (32\%) a 24\% respondentov sa priznalo, že tento systém nepozná.

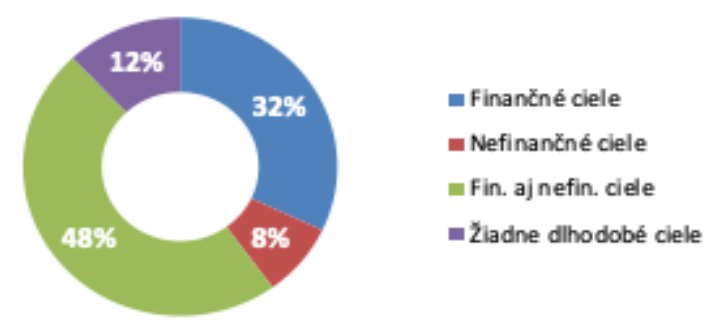

Obr. 3: Početnost' respondentov podl’a druhu stanovených dlhodobých ciel'ov, zdroj: vlastné spracovanie 
Proces induktívnej štatistiky podl'a Rimalčíka (2007), teda proces zovšeobecňovania úsudkov o vlastnostiach populácie podl’a informácií z náhodnej vzorky, je založený na štandardných chybách, pričom štandardná chyba štatistiky s rastom vel'kosti vzorky klesá.

Sme si vedomí skutočnosti, že vel'kost' nami vybranej náhodnej vzorky je relatívne malá v porovnaní s vel'kost'ou základného súboru, t.j. populácie, čím vel'kost' štandardnej chyby rastie. Taktiež $77 \%$ návratnost' dotazníka sa síce dá považovat' za uspokojivé číslo, avšak z hl'adiska využitia teórie pravdepodobnosti je nepostačujúce. Ciel’om nášho prieskumu však nebolo detailné poznanie problematiky Balanced Scorecard v podmienkach SR, našim ciel'om bolo poukázat' na to, do akej miery systém BSC manažéri organizácií poznajú, resp. ho využívajú.

Ako vyplýva z realizovaného prieskumu, znalost’ systému BSC v podmienkach SR je na pomerne nízkej úrovni. Napriek tomu, že takmer polovica respondentov si uvedomuje dôležitost' nielen finančných, ale aj nefinančných ciel'ov a ukazovatel'ov, takmer štvrtina opýtaných o systéme BSC nikdy nepočula, teda nedokáže posúdit' a využit' výhody, ktoré tento celosvetovo uznávaný manažérsky nástroj ponúka.

\section{NÁVRH KONCEPTU BSC SYSTÉMU V PODNIKU AUTOBUSOVEJ DOPRAVY}

Pri riešení problematiky zefektívnenia strategického riadenia podnikov autobusovej dopravy s využitím koncepcie BSC navrhujeme vytvorit' efektívny systém riadenia stratégie. Tento systém pozostáva zo 6 fáz, ktoré prebiehajú v neustálom kolobehu:

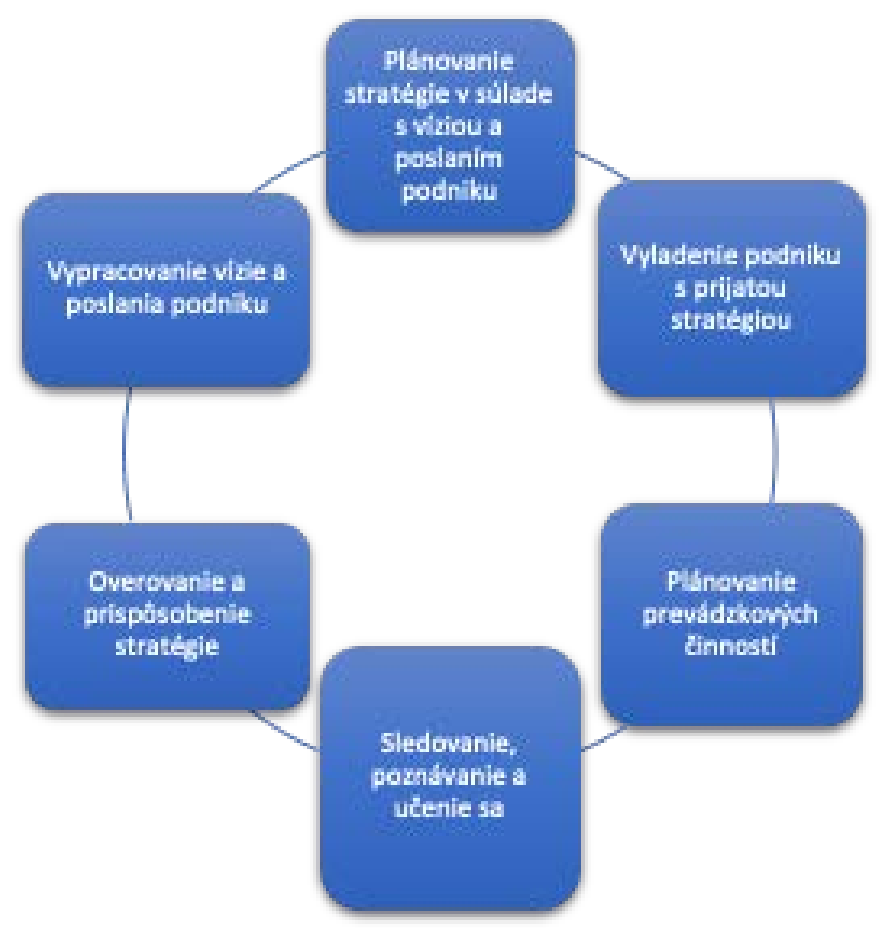

Obr. 4 Návrh procesu strategického riadenia v podniku autobusovej dopravy, zdroj: vlastné spracovanie

Za prvú fázu považujeme fázu vypracovania vízie a poslania podniku. Až ked’ je jasne stanovená a formulovaná vízia a poslanie podniku je možné plánovat' spôsob, ako ich dosiahneme vo forme realizovatel'nej stratégie. Podniky autobusovej dopravy v súčasnosti zvyčajne nemajú jednoznačne definovanú víziu ani poslanie. Toto je náročný proces, ktorý je v kompetencii vrcholového manažmentu, a je potrebné mu venovat' zvýšenú pozornost'. V d’alšej fáze systému riadenia stratégie dochádza $\mathrm{k}$ jej premene na konkrétne ciele, meradlá, ich ciel'ové hodnoty a strategické akcie. Taktiež je dôležité aj jej vnútorné vyladenie a následne plánovanie prevádzkových činností. Významným nástrojom využívaným v týchto fázach je strategická mapa. Strategická mapa predstavuje logickú a ucelenú architektúru 
pre zobrazenie konkrétnej stratégie. Kraus a Lind (2010) popisujú proces vytvárania hodnoty prostredníctvom príčinných väzieb medzi ciel’mi v rámci jednotlivých perspektív systému BSC.

Gorzelańczyk, Kaczmarek (2019) tvrdia, že aby mohol podnik zlepšovat' svoju činnost', procesy aj výsledky, musí ich vediet' zmerat'. Z tohto dôvodu je nutné k stanoveným ciel'om priradit' vhodné ukazovatele, t.j. meradlá, ich ciel'ové hodnoty a akcie vedúce k ich naplneniu. Pre každý strategický ciel' zobrazený v mape stratégie je potrebné určit' aspoň jedno meradlo, ktoré umožní zmerat' a zhodnotit' úspešnost' zvolenej stratégie. Je však potrebné uvedomit’ si, že sa jedná nielen o finančné meradlá, ale aj o meradlá nefinančné, ktoré sú často t’ažko kvantifikovatel'né, preto si výber vhodných meradiel vyžaduje náležitú pozornost'.

Ciel’ové hodnoty sú hodnoty zvolených ukazovatel'ov, ktorých reálne dosiahnutie sa v záujme naplnenia určeného poslania podniku očakáva v budúcnosti. Pri ich identifikácii berieme do úvahy súčasný stav zvolených ukazovatel'ov, náročnost' stanovených ciel'ov, poprípade môžeme využit' dostupné údaje konkurenčných podnikov.

Po úspešnej identifikácii strategických ciel’ov, meradiel a ich ciel’ových hodnôt je potrebné určit' aktivity, pomocou ktorých sa podnik dostane na správnu cestu k realizácii svojej stratégie a naplneniu poslania. Tieto strategické akcie teda určujú spôsob, akým chce podnik dosiahnut’ stanovené hodnoty strategických ciel'ov. Aby sa zabezpečila realizácia a prehodnocovanie určených strategických akcií, pridel'uje sa každej strategickej akcii osoba zodpovedná za jej priebeh.

V d'alšom kroku systému riadenia stratégie dochádza $\mathrm{k}$ jej vylad’ovaniu s jednotlivými organizačnými jednotkami a s jednotlivými zamestnancami, ktoré má pre úspešnú implementáciu stratégie kritický význam. $\mathrm{V}$ procese vylad’ovania jednotlivých zamestnancov so stratégiou podniku má kl'účový význam najmä ich informovanost'. Pokial' všetci zamestnanci nebudú poznat' stratégiu podniku a rozumiet' jej, je vel'mi nepravdepodobná úspešnost' implementácie stratégie. Vhodným komunikačným prostriedkom napomáhajúcim dosiahnutie tejto podmienky je organizácia porád. Pokial' podnik nedokáže previazat' svoju stratégiu s prevádzkovými činnost’ami aj na tej najnižšej úrovni riadenia, nebude možné dokonale prepracovanú stratégiu využit' a premenit' na naplnenie želanej vízie a poslania podniku. Takéto prepojenie stratégie s prevádzkovými procesmi rieši práve štvrtá fáza použitého systému riadenia stratégie, ktorá sa skladá z dvoch častí.

Sformulovaním stratégie a spracovaním plánu prevádzkových činností, sa podl’a Barrubés a Bisbe (2012) podnik vydáva na cestu realizácie stratégie, ktorá ho má v nasledujúcich rokoch doviest' k naplneniu svojej vízie a poslania. Výborne sformulovaná stratégia aj jej dokonalá realizácia však ešte nemusia zaručit' dosiahnutie naplnenia želaného poslania podniku. Dôvodom je dynamický vývoj v makroekonomickom, konkurenčnom či technologickom prostredí podniku, ktorý môže byt' príčinou zastaranej či dokonca nerealizovatel'nej stratégie. Záverečnou fázou použitého systému riadenia stratégie je teda jej overovanie a prispôsobovanie. Ide zároveň o fázu nadväzujúcu na začiatočnú fázu realizácie stratégie, ked'že v prípade zistenia nežiaduceho smerovania podniku alebo významných zmien v okolí podniku, dochádza k opätovnej realizácii strategickej analýzy a formulácii aktuálnej stratégie.

\section{NÁVRH STRATEGICKEJ MAPY BSC SYSTÉMU V PODNIKU AUTOBUSOVEJ DOPRAVY}

Pre vytvorenie strategickej mapy BSC systému pre podnik autobusovej dopravy je potrebné zadefinovat' jednotlivé perspektívy BSC systému a následne v týchto perspektívach stanovit’ sledované ukazovatele a meradlá.

V rámci perspektívy učenia sa a rastu pre podniky autobusovej dopravy navrhujeme zefektívnenie informačného systému ako nevyhnutnej súčasti fungovania celého podniku. Ako vhodné meradlá odporúčame kvalitu internej komunikácie a prístup k informáciám. Vhodnými strategickými akciami sú aktualizácia softvéru, ktorý poskytuje svojim užívatel’om potrebnú informačnú základňu, ale aj organizácia 
pravidelných porád, ktoré slúžia na výmenu informácií nevyhnutných pre prijímanie správnych rozhodnutí. Zvyšovanie kvalifikácie zamestnancov je d’alším významným strategickým ciel’om ovplyvňujúcim kvalitu množstva interných procesov v podniku. Jeho plnenie navrhujeme merat' pomocou počtu preškolených osôb, podla objemu tržieb pripadajúcich na jedného pracovníka, kde predpokladáme neustály medziročný rast a pomocou počtu reklamácií, ktoré by mali naopak medziročne klesat'. $\mathrm{K}$ dosiahnutiu tohto ciel'a by mala prispiet' účast' na vhodných školeniach a workshopoch, ale aj zvýšenie požiadaviek na uchádzačov o nové pracovné miesta. Podnik môže optimálne využit' potenciál svojich zamestnancov plnením ciel’a v oblasti ich motivácie. Liižbetinová a Hitka (2016) navrhujú využit’ finančné ukazovatele týkajúce sa medziročného rastu mzdových nákladov a výdavkov zo sociálneho fondu, ale aj ukazovatel' nefinančný, a to hodnotenie spokojnosti zamestnancov na základe každoročne vykonávaných prieskumov spokojnosti. Potrebnými aktivitami sú tu vhodne nastavený mzdový systém pridel'ovania prémií podla výkonu zamestnancov, odmeňovanie ich zlepšovacích návrhov a podnetov, vítaným benefitom môže byt' poskytovanie príspevkov zo sociálneho fondu aj rodinným príslušníkom zamestnancov.

V rámci perspektívy interných podnikových procesov navrhujeme sledovat’ proces „prípravy zákazky“ vo forme cestovných poriadkov pre pravidelnú aj nepravidelnú autobusovú dopravu a ich optimalizáciu s dôrazom na skrátenie a zefektívnenie prepravy cestujúcim a efektívneho využitia všetkých kl'účových liniek, ktoré podnik autobusovej dopravy vykonáva. Upozorňujeme, že podl'a Beňovej, Gnapa a Harantovej (2019) je v tejto perspektíve potrebné zvlášt' venovat' zvýšenú pozornost' zo strany manažmentu podniku.

Predchádzajúce dve perspektívy spolu so svojimi strategickými ciel'mi, meradlami a akciami odrážajú spôsob, akým chce podnik dosiahnut' žiadané výsledky v oblasti perspektívy zákazníckej a finančnej. Zvolené strategické ciele, meradlá a akcie perspektívy zákazníckej a finančnej následne popisujú, čo chce podnik dosiahnut'. Vo všeobecnom ponímaní podl’a Doušu (2019) ide o vytváranie hodnoty pre vlastníkov podniku prostredníctvom zvyšovania tržieb a produktivity a tiež o dosiahnutie vyššieho podielu na výdavkoch zákazníkov prostredníctvom získavania zákazníkov, ich udržania, spokojnosti, lojality a ich rozvoja.

Zákaznícka perspektíva odzrkadl'uje zákazníka a ako zdôrazňujú Trnka a Gogola (2019) jeho spokojnost' s premiestnením. V rámci zákazníckej perspektívy sme za strategické ciele určili zvýšenie počtu verných zákazníkov, udržanie vernosti zákazníkov a zvýšenie spokojnosti zákazníkov.

Dosiahnutie splnenia ciel'ov finančnej perspektívy je z pohl’adu Gorzelańczyka a Kaczmareka (2019) posledným krokom k naplneniu stanovenej vízie a poslania podniku autobusovej dopravy. Za hlavné strategické ciele tejto perspektívy sme určili štandardné finančné ukazovatele, výšku celkových nákladov a výšku investičných nákladov na obnovu vozového parku.

Výsledkom zadefinovania jednotlivých perspektív je vytvorenie už spomínanej strategickej mapy (vid' obr. 5) Z nášho pohl'adu sa podnik autobusovej dopravy môže „inšpirovat"“ nami vytvorenou strategickou mapou, ktorá odzrkadl'uje špecifiká podnikania v osobnej autobusovej doprave. Upozorňujeme však, že v praxi je potrebné vytvorit’ vlastnú strategickú mapu, ktorá rešpektuje zadefinovanú víziu, poslanie a ciele podniku. Veríme, že tento návrh poskytuje dostatočný návod, ako vytvorit’ tú „svoju“.

Vytvorenie strategickej mapy dáva podklad pre vytvorenie a následne využívanie koncepcie BSC systému v podniku autobusovej dopravy. 


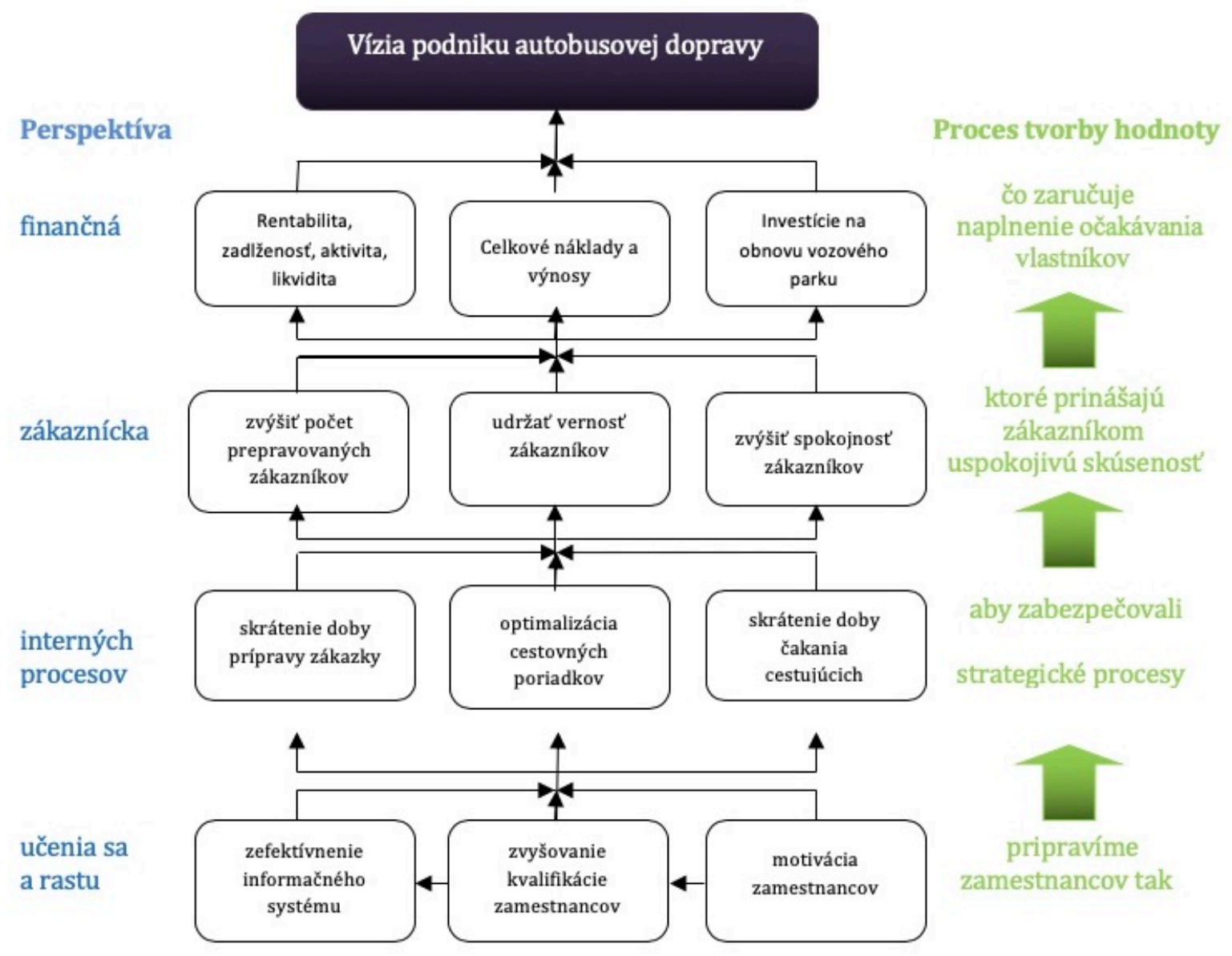

Obr. 5 Návrh strategickej mapy pre podnik autobusovej dopravy, zdroj: vlastné spracovanie

\section{PRÍNOSY A RIZIKÁ METODIKY BSC SYSTÉMU V PODNIKU AUTOBUSOVEJ DOPRAVY}

Od každej zrealizovanej zmeny v podniku je očakávaný jej pozitívny vplyv na súčasnú výkonnost’ a tak je tomu aj v prípade využitia metodiky BSC. Aby uskutočnené opatrenia priniesli v podniku požadovaný efekt, je nutné dbat' na ich pravidelné zlepšovanie a úpravu podl'a meniacich sa potrieb podniku. Klúčovým prínosom využitia systému BSC v strategickom riadení podniku autobusovej dopravy je presadenie jeho stratégie a pomocou vhodne zvolených strategických ciel'ov, meradiel a akcií úspešné naplnenie poslania i vízie podniku. Podnik dosiahne úspech nielen vo zvýšení finálnych finančných ukazovatel'ov akými sú napríklad objem tržieb, zisku či rentabilita vloženého kapitálu, ale aj v oblasti zatial' často nedoceňovaných nefinančných ukazovatel'ov, ktoré sa významnou mierou podiel’ajú na získaní konkurenčnej výhody podniku. Využitím nefinančných ukazovatel’ov akým je napríklad hodnotenie spokojnosti zákazníka sa podnik zameriava aj na vylepšenie starostlivosti o zákazníka a snahu čo najlepšie vyhoviet' jeho požiadavkám, čo sa prejaví vo vernosti zákazníkov a posilnení dobrého mena podniku. V rámci oblasti interných podnikových procesov dôjde k skvalitneniu a spresneniu informácií o ich priebehu, k snahe o ich neustále zlepšovanie a odstraňovanie úzkych miest. Ked’že k nevyhnutným podmienkam úspešnosti podniku patria aj jeho spokojní a motivovaní zamestnanci, prínos konceptu BSC je v neposlednom rade aj v previazaní systému odmeňovania s dosahovaním ciel'ových hodnôt jednotlivých ukazovatel'ov, v zvýšení informovanosti zamestnancov a podpore zlepšovacích návrhov z ich strany.

S konceptom BSC sú však spojené aj určité riziká, ktoré môžu bránit' jeho efektívnemu využitiu a odklonit' podnik zo správnej cesty k naplneniu želaného ciel'a. Medzi najväčšie riziká patria nesprávne nastavené 
meradlá, ktorých sledovanie nemusí signalizovat' plnenie strategických ciel’ov. Podnik sa tak zameria na nesprávne činnosti, ktoré sú z hl'adiska naplnenia poslania podniku nepodstatné. Taktiež samotné strategické ciele, či dokonca samo poslanie podniku, ktoré sa zdali byt' reálne a dosiahnutel'né, sa môžu stat' nesplnitel'nými, a to jednak z príčin na strane podniku, jednak z príčin podnikom neovplyvnitel'ných. Z tohto dôvodu je potrebné neustále sledovat' zmeny v externom i internom prostredí podniku. Prekážkou, pri ktorej zlyháva množstvo podnikov snažiacich sa o implementáciu systému BSC, je prepojenie podnikovej stratégie s ciel'mi jednotlivých útvarov podniku, oddelení alebo jednotlivcov. Nevyhnutnou podmienkou využitia konceptu BSC je taktiež skutočnost', aby všetci zamestnanci pochopili a prijali jeho podstatu, inak celý ret’azec príčinných súvislostí tvoriaci podstatu konceptu BSC stratí význam a je odsúdený na stroskotanie.

\section{ZÁVER}

V príspevku sme poukázali na široké spektrum využitia BSC systému aj v podnikoch autobusovej dopravy, na jej prínosy ale aj riziká. Súčasný trend vývoja trhovej ekonomiky je dynamický a nepredvídatel'ný. Súčasnú „našliapnutú“ ekonomiku doslovne zabrzdila pandémia s názvom Covid - 19. Aký bude budúci vývoj je v momentálnej situácii vel'mi náročné predpovedat'. Je však potrebné nájst' nové riešenia, ktoré bud' povedú k zmene systému, na ktorý sme „zvyknutí", resp. bude nevyhnutné „naštartovat“" nový dopyt a ponuku. Jednou z možností sú aj nové technológie, ktoré aj v oblasti dopravy môžu zmenit' celé smerovanie súčasne riadených podnikov autobusovej dopravy. Z tohto dôvodu bude ale nevyhnutné prehodnotit' aj celé riadenie a strategické riadenie týchto podnikov. Aj z tohto dôvodu dávame do pozornosti metodiku BSC systému, ktorá síce nie je úplným nováčikom v strategickom riadení podnikov, ale jej využitie, resp. využitie jej metodiky môže pomôct’ v získaní konkurenčnej výhody a správneho strategického postavenia aj v oblasti autobusovej dopravy.

\section{Literatúra}

Agostino, D., Arnaboldi, M. 2012. Design issues in Balanced Scorecards: The "what" and "how" of control. European Management Journal, 30(4), s. 327-339.

Barrubés, J., Bisbe, J. 2012. The Balanced Scorecard as a Management Tool for Assessing and Monitoring Strategy Implementation in Health Care Organizations. Revista Española de Cardiología (English Edition), 65(10), s. 919-927.

Beard, F. D. 2015. Successful Applications of the Balanced, Scorecard in Higher. Journal of Education for Business, 84(5), s. 275-28.

Beňová, D., Gnap, J., Harantovaá, V. 2019. Regulation of Traffic to the City Centre Based on Urban Electronic Toll. Perner's Contacts, 14(3), s. 5-13. [Online]. Dostupné z:

http://pernerscontacts.upce.cz/56 2019/Benova.pdf [cit. 2020-06-28].

Bhagwat, R., Sharma, M. K. 2007. Performance measurement of supply chain management: A balanced scorecard approach. Computers \& Industrial Engineering, 53(1), s. 43-62.

Douša, M. 2019. Úloha dopravy při plnění cílů udržitelného rozvoje [Role of Transport in Realising the Sustainable Development Goals]. Perner's Contacts, 14(1), s. 47-57. [Online]. Dostupné z: http://pernerscontacts.upce.cz/54 2019/Dousa.pdf [cit. 2020-06-28].

Fibírová, J., Šoljaková, L. 2005. Hodnotové nástroje řízení a měření výkonnosti podniku. 1. vydání, Praha: ASPI. s. 263, ISBN 80-7357-084-X.

Gavurová, B. 2011. The Balanced Scorecard in Enterprise Management. Economic magazine, s. 163-177. 
Gorzelańczyk, P., Kaczmarek, L. 2019. Wpływ nowoczesnych systemów informatycznych na eksploatację pojazdów osobowych [The influence of modern information systems on the operation of passenger vehicles]. Autobusy - Technika, Eksploatacja, Systemy Transportow, 227 (1-2), s. 211-215.

Horváth \& Partner, 2002. Balanced Scorecard v praxi. Praha: Profess Consulting, ISBN 80-7259-033-2.

Kaplan, R., Norton, D. 2001. The strategy-focused organization: how balanced scorecard companies thrive in the new business environment. Boston : Harvard Business School Press, s. 400, ISBN 1-57851-250-6.

Kaplan, R. S., Norton, D. P. 2007. Balanced scorecard: Strategický systém měření výkonnosti podniku. Praha: Management Press, s. 267, ISBN 978-80-7261-177-5.

Kraus, K., Lind, J. 2010. The impact of the corporate balanced scorecard on corporate control - A research note. Management Accounting Research, 21(4), s. 265-277.

Lawrie, G., Cobbold, I. 2004. Third-generation balanced scorecard: evolution of an effective strategic control tool. International Journal of Productivity and Performance Management, 53(7), s. 611-623. https://doi.org/10.1108/17410400410561231.

Ližbetinová, L., Hitka, M. 2016. Selection of Most Suitable Candidates for the Talent Pool in a Furniture Manufacturing Company. Drvna industrija: Znanstveni časopis za pitanja drvne tehnologije, 67(4), s. 333340.

Rimalčík, M. 2007. Štatistika pre prax. Vydané nákladom vlastným, s. 200, ISBN 978-80-969813-1-1.

Sancho, M.R. 2016. BSC Best Practices in Professional Training and Teaching for the HPC Ecosystem. Journal of Computational Science. Journal of computational science, 14, s. 74-77.

Trnka, L., Gogola, M. 2019. Analysis of the tire contact area pressure on the road. Perner's Contacts. 14(2), s. 49 - 59. [Online]. Dostupné z: http://pernerscontacts.upce.cz/55_2019/Trnka.pdf [cit. 2019-06-28].

Wang, S. H. et al. 2015. Using Balanced Scorecard for Sustainable Design-Centered Manufacturing. Procedia Manufacturing, 1, s. 181-192. 